\title{
Exposed Gamma Doses in air and Assessment of Cancer Risk around Gebze (Kocaeli/Turkey) Region
}

\author{
Muttalip Ergun Turgay ${ }^{1 *}$, Zeynep Acar ${ }^{2}$, Zeki Ünal Yümün ${ }^{3 \dagger}$, Arev Artun $^{4}$, Erol Kam ${ }^{5}$ \\ 1 Yalova University, Faculty of Engineering, Yalova, Turkey, (ORCID: 0000-0003-1708-8283), eturgay20@ hotmail.com \\ ${ }^{2}$ Yildiz Technical University, Faculty of Arts and Sciences, İstanbul, Tekirdağ (ORCID: 0000-0003-2159-1930), zeynep.karaalioglu@ @otmail.com \\ $3^{3 *}$ Namık Kemal University, Faculty of Engineering, Departmant of Enviromental, Tekirdağ, Turkey, (ORCID: 0000-0003-0658-0416), zyumun@nku.edu.tr \\ ${ }^{4}$ Yildiz Technical University, Faculty of Arts and Sciences, Departmant of physics, İstanbul, Turkey, (ORCID: 0000-0002-6868-9890), arevartun@gmail.com \\ ${ }^{5}$ Yildiz Technical University, Faculty of Arts and Sciences, Departmant of physics, İstanbul, Turkey, (ORCID: 0000-0001-5850-5464), erolkam@yildiz.edu.tr
}

(First received 16 January 2021 and in final form 14 May 2021)

(DOI: $10.31590 /$ ejosat.862361)

ATIF/REFERENCE: Turgay, M. E., Acar, Z., Yümün, Z. Ü., Artun, A. \& Kam, E. (2021). Exposed Gamma Doses in air and Assessment of Cancer Risk around Gebze (Kocaeli/Turkey) Region. European Journal of Science and Technology, (25), $139-144$.

\begin{abstract}
By this study, it is focused to assessment of inhalation quality for Kocaeli province especially Northeast side of Marmara Sea (Gebze county and its territory). In this case, radioactivity analysis in air was realized via air dose rate measurements around this region which is so closed neighbor to big city Istanbul. By measuring of the outdoor gamma dose rates on 35 stations, it was possible to get the average dose rate. Then it was calculated to annual dose in air. Besides, cancer risk was determined for Kocaeli. All these values were compared with the World's references (UNSCEAR) and reported finally. It was measured the average dose rate as $\mathbf{2 3 . 9 0} \mathbf{~ n G y h r} \mathbf{r}^{\mathbf{1}}$ and annual dose was calculated to $\mathbf{2 9 . 3 1} \boldsymbol{\mu S v}$. This dose is required to excess lifetime cancer risk as $\mathbf{1 . 0 2 \times 1 0}^{-4}$. These values could be compared to the similar studies which existed around the world. Finally, the average annual effective dose equivalent and excess lifetime cancer risk for Kocaeli, are less than the world average. This study would be used to a reference for further investigations, besides it will be usefull to compare with different studies for Kocaeli which, will be evaluated in the future, for example after a nuclear pollution, such as based on a reactor leakage comes from Black Sea region and neighbours, nuclear attacks, etc., too. Another benefit would be made to enlarge to find this kind of studies in literature.
\end{abstract}

Keywords: Dose rate, AEDE, Outdoor Gamma, E.L. Cancer Risk, Kocaeli

\section{Gebze (Kocaeli / Türkiye) Bölgesinde Maruz Kalınan Gama Doz Değerleri ve Kanser Riskinin Değerlendirilmesi}

$\ddot{O} \mathbf{z}$

Bu çalışmada Kocaeli ili, özellikle Marmara Denizi’nin kuzeydoğu tarafı (Gebze ili ve çevresi) gama doz değerleri ile kanser risk değerleri araştırılmıştır. Açık havadaki radyoaktivite analizleri, İstanbul'a yakın olan bu bölge için gama doz hızı ölçümleri ile gerçekleştirilmiştir. Çalışma alanında 35 bölgede dış ortam gama doz oranları ölçülerek ortalama doz oranı elde etmek mümkün olmuştur. Daha sonra yıllık gama doz değerleri hesaplanmıştır. Ayrıca bu değerler kullanılarak kanser risk değerleri elde edilmiştir. Tüm bu değerler Dünya Referans değerleri (UNSCEAR) ile karşılaştırılmıştır. Analiz sonucunda ortalama gama doz hızı 23.90 $\mathrm{nGyhr}^{-1}$, yıllık doz hızı ise $29.31 \mu \mathrm{Sv}$. Yaşam boyu kanser risk değeri 1.02x10 ${ }^{-4}$ olarak hesaplanmıştır. Bu değerler, dünya çapında var olan benzer çalışmalarla karşılaştırılabilir. Sonuç olarak, Kocaeli için ortalama yıllık etkin doz değeri ve yaşam boyu kanser riski değeri dünya ortalamasının altındadır. Bu çalışma, ileride yapılacak araştırmalar için referans olarak kullanılacağı gibi, ileride Kocaeli için farklı çalışmalarla karşılaştırılmasında faydalı olacaktır, örneğin bir nükleer kirlilikten sonra örneğin Karadeniz'den gelen reaktör sızıntısı gibi.

Anahtar Kelimeler: Gama doz, Y1llık etkin doz, Kanser risk, Kocaeli

\footnotetext{
* Başlica Yazar: eturgay20@ @otmail.com

† Sorumlu Yazar: zyumun@nku.edu.tr
} 


\section{Introduction}

Radioactivity which a randomize event, occurs naturally (primordial nuclides) or by artificial processes. The largest contribution to total radiation dose whichever received by humans, comes from Natural Radiation. Therefore, environmental radioactivity measurements are necessary for determining the background radiation level especially due to natural radioactivity sources. The natural radiation which measured outdoor gamma dose, consist of cosmic rays and terrestrial components. Terrestrial radiation can be measured via gamma-ray spectroscopy separately. By the way, cosmic effects would be calculated by subtracting of terrestrial from measured outdoor gamma dose, too. The United Nations Scientific Committee on the Effects of Atomic Radiation (UNSCEAR, 2008) estimates the global average human exposure from natural radiation sources as $2.4 \mathrm{mSv}$ per year and the radionuclides that are present of soil samples (terrestrial components) are considered to be responsible for a portion of this amount [1]. Rest amounts are originated water and air, too.

\subsection{Literature Survey}

Over the past two decades, a few results due to radioactivity levels have been published in some papers related gamma dose rates in air for Turkish provinces ([2] to [12]). Near by, there is no study for Kocaeli region in literature especially. Therefore, the purpose of this study is to measure dose rates in air from different locations throughout the city and then assess the cancer risk to human life by calculation of the outdoor gamma dose. The human population in this city is up to one million and this study will be baseline for next studies about environmental radioactivity measurements, too.

By the way, there are also stated the worldwide studies in literature. As an example of them; in 2002, Ghiassi and Mortavazi have measured the absorbed gamma dose rates in air for Ramsar region of Persia. They have studied the effects of radiation on human life. The annual dose was also calculated that it is $260 \mathrm{mSv}$ and this value is more higher than the stipulated annual limit of $20 \mathrm{mSv}$ in North Persia. In genetic works, the effects of this high level were obtained the differency of the blood lenfosid samples of humans [13]. Another researches were also evaluated for Brasil and Canary Island [14] and [15], too.

\subsection{Measuring DistricT}

\subsubsection{Geographically Analysis}

Kocaeli province is existed on east of Marmara Region and coordinates are as well as 400 31/ - 420 42/ latitudes and 290 22/ - 310 22/ longitudes. Neighbours could be written as; North side, Black Sea and Şile district (Istanbul); East side, Sakarya province; South side, Yalova and Bursa provinces; West side, İstanbul province. Kocaeli province has 6 county except İzmit (central) and totally 653 settlements. Counties are Derince, Gebze, Gölcük, Kandıra, Karamürsel and Körfez. Kocaeliİstanbul border contents east of Kemikli River; Kocaeli- Bursa border lines Samanlı Mountains; Kocaeli-Sakarya border stars east Eşme and Maşukiye's east regions. Kocaeli spans an area of $3.626 \mathrm{~km}^{2}$. Population is around two million (Wikipedia, 2019 [16]).

\subsubsection{Topografic Analysis}

Region consists of the mountains cumulatively as \% 19. North side, by hill by consequently, South side, Samanlı Mountains continiously. Samanlı Mountains exists from Armutlu peninsula and followed west-east lines. Its lenght is $130 \mathrm{~km}$ and wideth is $30 \mathrm{~km}$. Highest pick is Kartepe $(1601 \mathrm{~m})$ and the others; Dikmen Mountain (1387 m) and Naldöken Mountain (1125 m), Naz Mountain (917 m) and Çene Mountain (646 m). Kocaeli has generally plateau and concerns around \%74.6. The most important plains are the Izmit plain between Izmit city and Sapanca Lake, the surface area of the Izmit plain between Dilovas1, Altınova in the Karamürsel and Sapanca lakes of the Izmit Gulf is $70 \mathrm{~km}^{2}$, and its height is $10 \mathrm{~m}$. It is a wet and fertile land and suitable for agriculture. Important rivers are Kocadere, Kaynarca, Doğancı and Sarısu; and Streams are Çayıvo, Hatipdere, Ağadere, Dereboğazıdere, Erenlerdere, Memelidere, Bekirdere, Serindere, Yalakdere and Çenesuyu river [17]. There are Sapanca and Herzegovina lakes within the provincial borders of Kocaeli. The width of the Lake of Sapanca starting from 17 $\mathrm{km}$ east of Izmit Bay and extending to $16 \mathrm{~km}$ east and $7 \mathrm{~km}$ of which is within the borders of Kocaeli is $5.5 \mathrm{~km}$ in the northsouth direction and its surface area is $47 \mathrm{~km} 2$. Samanlıdağları section of Kocaeli province is covered with forests. Generally, the upper parts of the mountains are covered with coniferous trees and the lower parts with broad-leaved trees. As you approach the sea, vegetation (maquis) of the Mediterranean climate is encountered. Fruit, vegetables and olives are dominant in the coastal regions of the province. Topografic map of Kocaeli is given in Figure 1 [17].

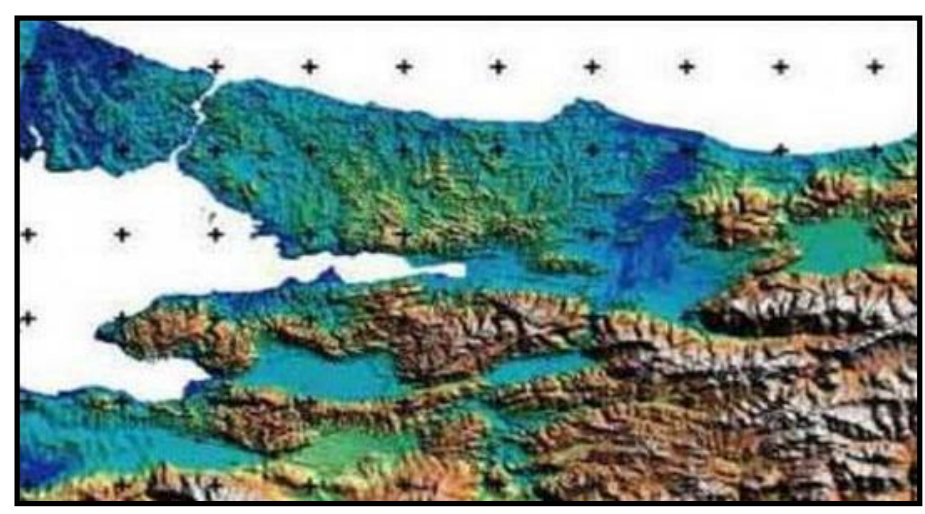

Figure 1: Topografic map of Kocaeli [17]

\subsubsection{Geomorphologic Analysis}

The northern part of Kocaeli province is an abrasion surface originated plateau area that corresponds to the water section area between the Black Sea and Izmit Bay (Marmara Sea) and constitutes the highest part of the Kocaeli Peninsula. Finally, the area, which was penetrated in Pliocene, completely increased during the "Post-Alpine" tectonic movements, the southern part was completely elevated, and later it was split into rivers and turned into a plateau. The average elevation in the western part is around $200-300 \mathrm{~m}$. The elevation value increases to the east and the field gets a hilly view with deep slope and valley slope. Shapes belonging to karst topography are commonly found in parts of the peninsula, which consist of molten (karstic) limestones. It is a typical section between the Triassic and Upper Cretaceous aged karstic limestones, between the Tavlili-Hereke line on the west of the Tavlili-Hereke line, and the area between the Dil Heresi-Tavsanli Creek-Ayvalık Stream on the east, and the area stretching up to Köseköy-Tepeköy in the north. In this area, where karstification is deep, there are numerous and varied 
karst depressions, dry valleys, subatans, criminals and caves, consisting of various lapias, dolinas and valas [17].

\section{Material and Method}

\subsection{Inhalation}

Airborne radioactivity, provides the first oppurtunity to identify the spectrum of radionuclides making up the contamination. Radionuclides will very rapidly appear in ground level air, and air samples can give the first indication of the nature of the contamination. Radioactive materials in the air may result in exposure to human by inhalation.

\subsection{Measuring points for gamma dose rates in air}

Coordinates are assigned by the GPS instrument which Macellan Explorist 510. There are 20 pcs different coordinates given in Table 1 for only Gebze county with dose rates together.

Table 1: Coordinates as classified due to Gebze county

\begin{tabular}{|c|c|c|c|c|c|}
\hline \multirow{3}{*}{$\begin{array}{c}\text { Measure } \\
\text {-ment } \\
\text { Location } \\
\text { s (ML) }\end{array}$} & \multirow{3}{*}{$\begin{array}{c}\begin{array}{c}\text { Dose } \\
\text { Rates } \\
\text { (nGy } \\
\mathbf{h r}^{1} \text { ) }\end{array} \\
10.45\end{array}$} & \multicolumn{4}{|c|}{ Coordinates } \\
\hline & & \multicolumn{2}{|c|}{ Latitude (pointed) } & \multicolumn{2}{|c|}{ Longitude (pointed) } \\
\hline & & $40.7977^{\circ}$ & 705699.67 & $29.4383^{\circ}$ & 4519161.00 \\
\hline ML-2 & 10.50 & $40.7979^{\circ}$ & 705656.87 & $29.4378^{\circ}$ & 4519182.04 \\
\hline ML-3 & 10.90 & $40.7978^{\circ}$ & 705598.12 & $29.4371^{\circ}$ & 4519169.29 \\
\hline ML-4 & 11.00 & $40.7979^{\circ}$ & 705783.42 & $29.4393^{\circ}$ & 4519185.56 \\
\hline ML-5 & 11.05 & $40.7970^{\circ}$ & 705541.53 & $29.4364^{\circ}$ & 4519078.83 \\
\hline ML-6 & 12.40 & $40.7975^{\circ}$ & 705691.85 & $29.4382^{\circ}$ & 4519138.57 \\
\hline ML-7 & 13.00 & $40.8137^{\circ}$ & 705667.11 & $29.4385^{\circ}$ & 4520937.80 \\
\hline ML-8 & 21.70 & $40.7980^{\circ}$ & 705867.48 & $29.4403^{\circ}$ & 4519199.01 \\
\hline ML-9 & 22.45 & $40.7975^{\circ}$ & 705835.28 & $29.4399^{\circ}$ & 4519142.56 \\
\hline ML-10 & 29.25 & $40.7973^{\circ}$ & 705717.78 & $29.4385^{\circ}$ & 4519117.07 \\
\hline ML-11 & 31.00 & $40.7972^{\circ}$ & 705709.65 & $29.4384^{\circ}$ & 4519105.73 \\
\hline ML-12 & 36.65 & $40.8138^{\circ}$ & 705633.06 & $29.4381^{\circ}$ & 4520947.97 \\
\hline ML-13 & 37.05 & $40.8149^{\circ}$ & 705612.79 & $29.4379^{\circ}$ & 4521069.62 \\
\hline ML-14 & 37.12 & $40.8146^{\circ}$ & 705681.20 & $29.4387^{\circ}$ & 4521038.19 \\
\hline ML-15 & 38.23 & $40.8145^{\circ}$ & 705689.94 & $29.4388^{\circ}$ & 4521027.32 \\
\hline ML-16 & 39.65 & $40.8148^{\circ}$ & 705714.32 & $29.4391^{\circ}$ & 4521061.34 \\
\hline ML-17 & 42.16 & $40.8136^{\circ}$ & 705658.98 & $29.4384^{\circ}$ & 4520926.47 \\
\hline ML-18 & 42.41 & $40.8133^{\circ}$ & 705626.17 & $29.4380^{\circ}$ & 4520892.22 \\
\hline ML-19 & 43.17 & $40.8142^{\circ}$ & 705707.74 & $29.4390^{\circ}$ & 4520994.49 \\
\hline
\end{tabular}

$$
\text { scintilation detector body (SPA-6) connected to the counter }
$$
(ESP-2), was selected to optimize its output for the radiation of interest. It provides the pulse signal to the electronics for counting. The pulse rate from the detector is proportional to the radiation field intensity at the detector. The high voltage supply provides the required bias voltage to the detector. The high voltage is keyboard adjustable and provides the correct operating voltages for a large selection of detectors. The low voltage supply regulates the operating voltage for the ESP-2 electronics as shown in Figure $2[18,23]$. The amplifier is a linear, adjustable gain, multistage design. It amplifies the signal from the probe to a usable level at the amplifier output. The discriminator provides a signal on its output only if the signal from the amplifier exceeds the adjustable threshold. This provides a means for rejecting noise and/or unwanted signal.

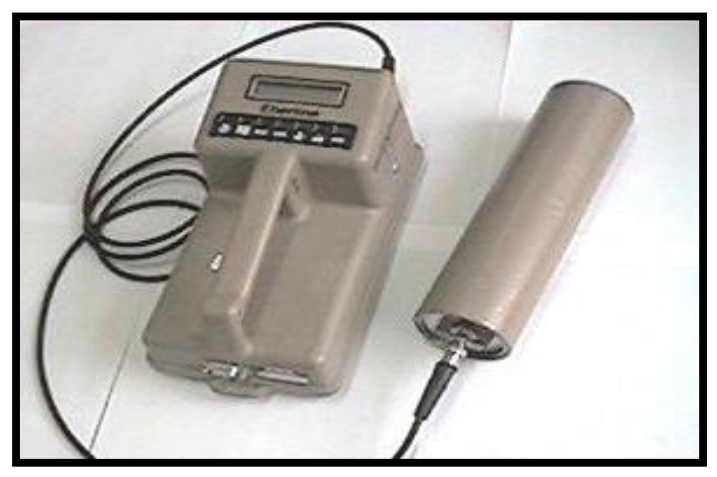

Figure 2: ESP-2 Rate meter and SPA-6 scintillation detector, Eberline [18]

\subsection{Outdoor dose rates as originated to the terrestrial effect and cosmic ray}

Absorbed gamma doses are originated to terrestrial and cosmic rays together. In order to obtain the absorbed gamma dose rates in air, the instrument was kept about 1 meter upperside from ground level. Because about on this level; it is important that how much dose exposed in air against to human gonad. The human gonad is the more important organ against to radiation damage. Annual doses in air were also calculated by using the gamma dose rates. Gamma dose rate information was given in Table 2. Related dose rate map was given in Figure 3, too. 
Table 2: ADRA values for Kocaeli Province

\begin{tabular}{|c|l|}
\hline $\begin{array}{l}\text { County Name } \\
\text { (nm. of sampling) }\end{array}$ & $\begin{array}{l}\text { Absorbed Gamma Dose } \\
\text { Rate (ADRA) [nGy hr-1 } \\
\text { average }\end{array}$ \\
\hline Kocaeli [rural areas*] (15) & 19.35 \\
\hline Gebze (20**) & 27.31 \\
\hline Total (35) & 23.90 \\
\hline
\end{tabular}

*In this study, total 15 different points were selected to take dose rate around Kocaeli rural (av. 19.35) lands as, Kumla River (6.10)- Karayakuplu (9.90)- Kandira (13.00)- Hediyeli (14.70)Demokrasi Park (14.75)- Dilovası (14.80)- Y. Hereke (15.18)Tavşancil (16.50)- Akçaova (16.60)- Yassıbağköy (17.35)Yağcılar (18.75)- Çakmaklarköy (26.59)- Derince (33.65)Körfez (34.85)- ÜtükDam (37.55).**Gebze county is a big industrial land and planned to take the dose rates from 20 stations in this county (Table 1). Regarding measured dose rates for 20 locations as well picked from Table 1, dose rate map is shown in Figure 3.

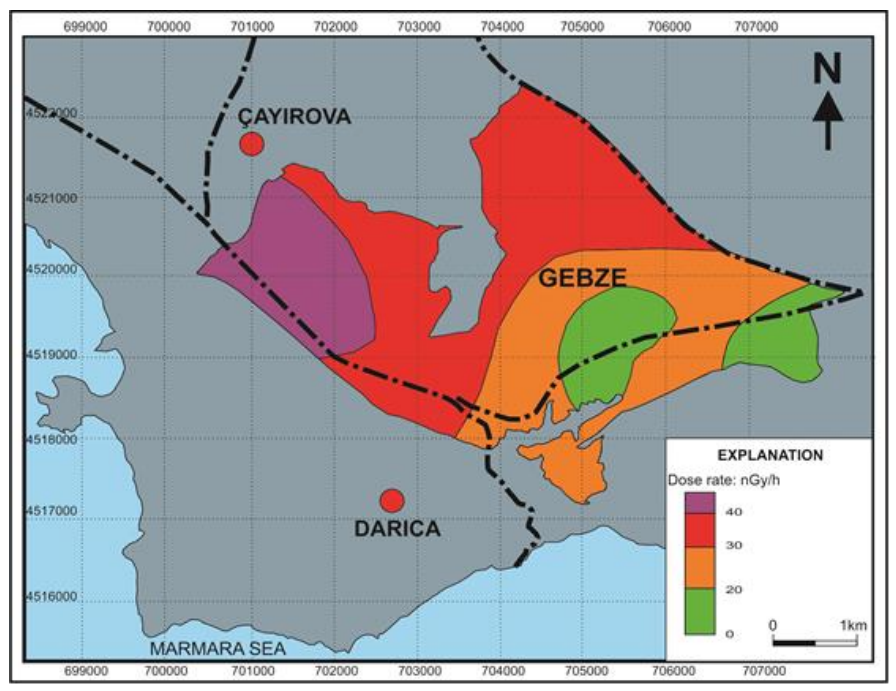

Figure 3: Outdoor Gamma Dose Rate $\left(n G y h^{-1}\right)$ map for Gebze and its territory

\section{Results and Discussion}

\subsection{Determination of Annual Effective Dose Equivalent (AEDE) and Excess Lifetime Cancer Risk (ELCR) by using Absorbed Gamma Dose Rates in air (ADRA):}

It is easy to calculate annual effective dose equivalent (AEDE) and Excess Lifetime Cancer Risk by using absorbed gamma dose rates, with reference of (UNSCEAR, 2008) [1]:

$A E D E=A D R A * D C F^{*} O F^{*} T$

Eq. 1
Where ADRA is absorbed dose rate in air $\left(\mathrm{nGyh}^{-1}\right)$, DFC is dose conversion factor $\left(0,7 \mathrm{~Sv} \mathrm{~Gy}^{-1}\right)$, OF is outdoor occupancy factor (0.2), $\mathrm{T}$ is exposure time $\left(8760 \mathrm{~h} \mathrm{y}^{-1}\right)$. AEDE is annual effective dose equivalent $(\mu \mathrm{Sv}), D L$ is duration of life (70 year), $\mathrm{RF}$ is risk factor $\left(\mathrm{Sv}^{-1}\right)$ as fatal cancer risk per $\mathrm{Sv}$ (calculate to stochastic effects; ICRP 60 [19]) uses value of 0.05 for the public (ICRP, 2007), ELCR is excess lifetime cancer risk.

\subsection{AEDE and ELCR values and Standard Deviations}

Annual doses and Cancer Risk values are given in Table 3 for Gebze and Rural districts of Kocaeli. Standard deviations were also calculated and given in below table, too. Due to large differency of the values, deviations were also obtained in high ratio as roughly $17 \%$ AEDE and $16 \%$ for ELCR.

$E L C R=A E D E^{*} D L^{*} R F$

Eq. 2

Table 3: AEDE and ELCR values for Kocaeli

\begin{tabular}{|c|c|c|c|c|}
\hline $\begin{array}{c}\text { County } \\
\text { Name }\end{array}$ & $\begin{array}{c}\text { (AEDE) } \\
{[\boldsymbol{\mu S v}],} \\
\text { average }\end{array}$ & $\begin{array}{c}\text { Standard } \\
\text { Deviation } \\
\text { for AEDE }\end{array}$ & $\begin{array}{c}\text { ELCR } \\
{[\mathbf{( x 1 0 - 4 )}} \\
\text { average }\end{array}$ & $\begin{array}{c}\text { Standard } \\
\text { Deviation } \\
\text { for ELCR }\end{array}$ \\
\hline $\begin{array}{c}\text { Kocaeli-rural } \\
\text { districts* (15) }\end{array}$ & 23.73 & - & 0.83 & - \\
\hline Gebze $\left(20^{* *}\right)$ & 33.49 & - & 1.17 & - \\
\hline Kocaeli (35) & 29.31 & 4.84 & 1.02 & 0.17 \\
\hline
\end{tabular}

\subsection{Comparison between OUR measurements to RESA's values}

TAEK, Turkish Atomic Energy Agency periodically measures the natural radiation in air by RESA [18,21,22] system which consist of a Geiger detector and reader, too. Due to locations of this system, there is one measuring point in Izmit as central county as referenced to Kocaeli province. Below pictures are referred the RESA system in Figure 4 clearly. It was observed online as $70 \mathrm{nSvh}^{-1}$ by RESA and it refers to $100 \mathrm{nGyh}^{-}$ ${ }^{1}$. Average of our measurements is 23.90 and maximum is 46.12 $\mathrm{nGyh}^{-1}$. There are a lot of possible reasons due to this differency.

One of them is that; Our measurements are not for only one fixed point as well as in RESA. Other reason would be the counting device type. RESA device is basic Geiger- Müller counter. Our device is scintillator and has higher efficiency. Measurement times are also another reason to this differency. Annual doses and Cancer risks were drawn in Figure 5 and Figure 6.

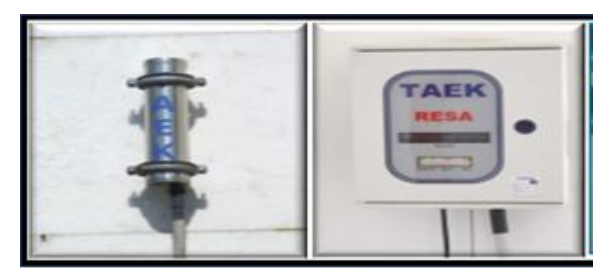

Figure 4: RESA detector- counter and control center, TAEK [20] 


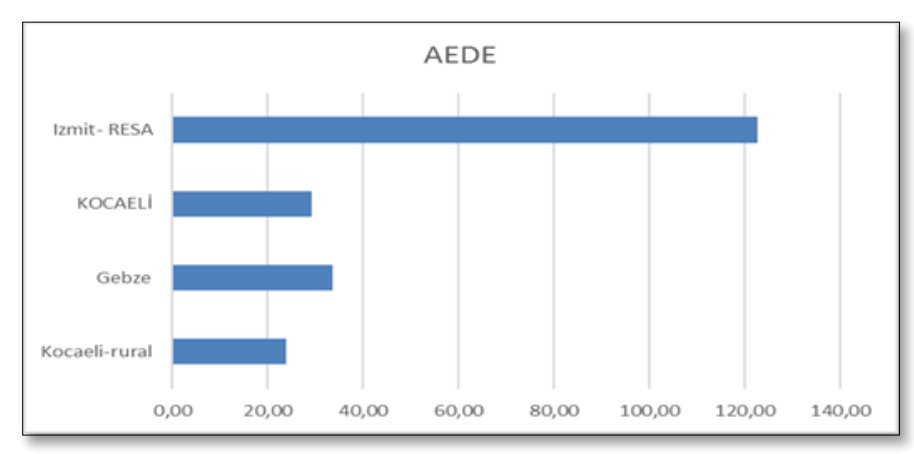

Figure 5: Horizontal Bar chart [AEDE in $\mu \mathrm{Sv}$ ]

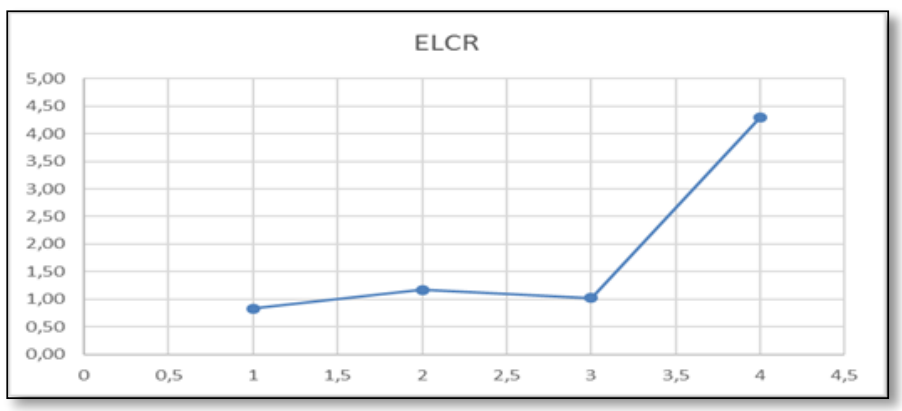

Figure 6: Line Graphic; Kocaeli-rural, Gebze, Kocaeli, IzmitRESA [ELCR, $\left.x 10^{-4}\right]$

\subsection{Statistics and comparison}

Similar studies which picked up from literature, were compared in Table 4, not only AEDE but also ELCR values, too.

Table 4: Comparison for AEDE and ELCR values

\begin{tabular}{|c|c|c|c|}
\hline $\begin{array}{c}\text { [ref no], } \\
\text { Region, } \\
\text { (nmof } \\
\text { samplings) }\end{array}$ & $\begin{array}{c}\text { (AEDE) } \\
{[\mu \mathrm{Sv}],} \\
\text { average }\end{array}$ & $\begin{array}{c}\text { ELCR } \\
{\left[\left(\mathrm{x} 10^{-4}\right)\right],} \\
\text { average }\end{array}$ & Reference, Year \\
\hline [02] Adana & 82.00 & 2.87 & Değerlier, et all., 2008 \\
\hline $\begin{array}{l}\text { [03]Ankara } \\
\quad(341)\end{array}$ & 71.83 & 2.69 & Kapdan, et all., 2018 \\
\hline $\begin{array}{l}\text { [04]Artvin } \\
\text { (204) }\end{array}$ & 214.50 & 7.50 & Taşkın, et all., 2015 \\
\hline $\begin{array}{l}\text { [05] Balıkesir } \\
(92)\end{array}$ & 156.30 & 6.30 & Kapdan, et all., 2011 \\
\hline $\begin{array}{c}\text { [06]Çanakkale } \\
\text { (379) }\end{array}$ & 81.40 & 2.85 & Kam, et all., 2007 \\
\hline $\begin{array}{l}\text { [07]Edirne } \\
\text { (14) }\end{array}$ & 47.30 & 1.66 & $\begin{array}{l}\text { Z.Ü.Yümün, et all., } \\
2018\end{array}$ \\
\hline $\begin{array}{l}{[* *] \text { Hatay }} \\
(215)\end{array}$ & 63.93 & 2.24 & M. E. TURGAY, ** \\
\hline [08] IDA (75) & 198.66 & 6.95 & $\begin{array}{l}\text { Muttalip Ergun } \\
\text { TURGAY, } 2019\end{array}$ \\
\hline [09] İstanbul & 79.72 & 2.79 & G. Karahan, A. \\
\hline
\end{tabular}

\begin{tabular}{|c|c|c|c|}
\hline (105) & & & Bayülken, 2000 \\
\hline $\begin{array}{l}{[10] \text { Kastamonu }} \\
(60)\end{array}$ & 58.88 & 2.06 & Kam, et all, 2007 \\
\hline [11] Şanlıurfa & 74.70 & 2.62 & Kam, et all, 2007 \\
\hline [12] Bolu (74) & 27.23 & 0.95 & $\begin{array}{l}\text { M. E. TURGAY, et } \\
\text { all., }\end{array}$ \\
\hline ThisStudy (35) & 29.31 & 1.02 & $\begin{array}{l}\text { M. E. TURGAY, et } \\
\text { all., ,... }\end{array}$ \\
\hline $\begin{array}{l}\text { [20]Kocaeli } \\
\text { (izmit) }\end{array}$ & 122.64 & 4.29 & $\begin{array}{l}\text { TAEK- Resa, } 365 \\
\text { days- online }\end{array}$ \\
\hline [1] World & 73.60 & 2.58 & UNSCEAR, 2008 \\
\hline $\begin{array}{l}\text { [13] R. D. J.- } \\
\text { Brasil }\end{array}$ & 90.00 & 3.15 & Licinio, et all., 2013 \\
\hline $\begin{array}{l}\text { [14]Ramsar- } \\
\text { IRAN }\end{array}$ & 105.00 & 3.68 & Ghiassi, et all., 2002 \\
\hline $\begin{array}{l}\text { [15] Canary I- } \\
\text { Spain }\end{array}$ & 91.95 & 3.22 & Arnedo, et all., 2017 \\
\hline
\end{tabular}

**Not published, yet.

Data which existed in Table 4, refers below distribution in Figure 7, regarding Excess Life Time Cancer Risk corresponding to Annual Effective Dose Equivalent.

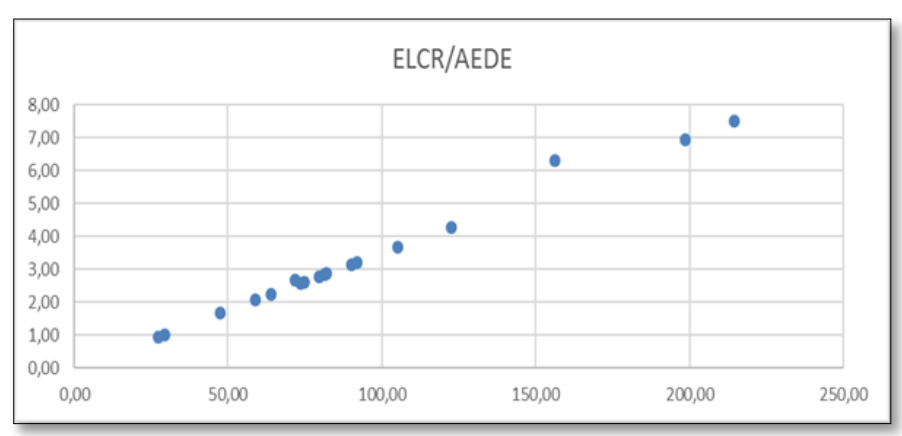

Figure 7: Distribution due to ELCR to AEDE $\left[x 10^{-4} ; \mu S v\right]$

\section{Conclusions and Recommendations}

Maximum dose rate for Kocaeli (Gebze district) was measured to $46.12 \mathrm{nGyhr}^{-1}$ and minimum was measured 6.10 $\mathrm{nGyhr}^{-1}$ for rural (around Kumla river). Maximum annual dose is calculated to $56.56 \mu \mathrm{Sv}$ and $1.98\left(\times 10^{-4}\right)$ as ELCR. Minimum annual dose is calculated to $7.48 \mu \mathrm{Sv}$ and $0.26\left(\times 10^{-4}\right)$ as ELCR. These values are a little bigger than the Bolu' $\mathrm{s}$ values which both provinces are neighbour. Kocaeli is important industry region and so close to Istanbul. Relatively low radiation values are important for regional population. This province has also seaside line along the Black Sea and open to any nuclear pollution which would be carried from Ukraine or Russia in the future. By this study, it will be one of the literature database due to comparison after a potentially nuclear pollution. Kocaeli is on the North Anatolian seismic zone and whether if any increasing of radiation doses would be shown the relation due to a seismic activity, too. In this moment, these results in our study, indicate 
that there is no risk originates to inhalation around Kocaeli province in Turkey.

\section{References}

[1] UNSCEAR., Report of the United Nations scientific committee on the effects of atomic radiation, sources, effects, and risks of ionizing radiation. United Nations Sales Publication, New York, 2008.

[2] M.Değerlier, G.KARAHAN, "Ph. D. Thesis: Annual Effective Dose of Natural Environmental Radioactivity Measurements for Adana region". N.S. Institue- CU/ Adana. 2007.

[3] E. Kapdan, N. Altınsoy, G. Karahan \& A. Yüksel, “Outdoor radioactivity and health risk assessment for capital city Ankara, Turkey", Journal of Radioanalytical and Nuclear Chemistry, 318. 1033-1042, 2018.

[4] Y. Kobya, H. Taşkın, C. M. Yeşilkanat \& U. Çevik, "Evaluation of Outdoor Gamma Dose Rate and Cancer Risk in Artvin Province, Turkey, Human and Ecological Risk Assessment: An International Journal, 21:8, 2077-2085, 2015.

[5] E. Kapdan, A. Varınlığlu \& G. Karahan, "Outdoor Radioactivity and Health Risks in Balıkesir, Northwestern Turkey", Radiation Protection Dosimetry, pp: 1-9, 2011.

[6] E. Kam, A. Bozkurt \& R. Ilgar "A study of background radioactivity level for Canakkale, Turkey". Environ Monit Assess, 168: 685-690, 2010.

[7] Z. Ü. Yümün, K. Bayrak, H. Aksoy \& U. Ayseli, “A Study of Background Radioactivity Level for Edirne, Turkey", Journal of Engineering Technology and Applied Sciences, 2018.

[8]M. E. Turgay, "Cancer Risk Determination for IDA villages by using Annual Gamma Doses in Air, around Edremit\&Ayvacık Districts; Balıkesir\&Çanakkale, TURKEY", European Journal of Science and Technology No 15, pp. 433-439, 2019.

[9] G. Karahan \& A. Bayülken, "Assessment of gamma dose rates around Istanbul (Turkey)", Journal of Environmental Radioactivity, 47, 213-221, 2000.

[10] E. Kam \& A. Bozkurt "Environmental radioactivity measurements in Kastamonu region of northearn Turkey", Applied Radiation and Isotopes, 65, 440-444, 2007.

[11] A. Bozkurt, N. Yorulmaz, E. Kam, G. Karahan \& A.E. Osmanlioglu, "Assessment of environmental radioactivity for Sanliurfa region of southeastern Turkey", Radiat. Meas., 42, 1387-1391, 2007.

[12] N.Z. Ateş, K. Bayrak, M.E. Turgay \& E. Kam, "Evaluation of Excess Lifetime Cancer Risk Caused by External Exposure due to Natural Radioactivity in Bolu, Turkey", Sigma Journal of Engineering and Natural Sciences, 38 (2), 945-954, 2020.

[13] M. Ghiassi, S. M. Mortazavi \& J. R., Cameron, "Very High Background Areas of Ramsar, Iran: Preliminary Biological Studies", Health Physics, 82(1), 87-93, 2002.

[14] M.V.,Lic'ınio, A.C. Freitas, H. Evagelista, A. CostaGonçalves, M. Miranda \& A.S. Alencar, "A high spatial resolution outdoor dose rate map of the Rio de Janeiro city, Brasil”, Risk Assessment and Urbanization Effects. J Environ Radioact 126, 32-9, 2013.

[15] M. A. Arnedo, J. G. Rubiano, H. Alonsa, A. Tejera, A. Gonzalez, J. Gonzalez, J.M. Gil, R. Rodriguez, P. Martel \& J.P. Bolivar, "Mapping natural radioactivity of soils in the eastern Canary Islands, Spain", Journal of Environmental Radioactivity, 166, 242-258, 2017.

[16] www.wikipedia.org. 2019.

[17] CED, Branch Management, 2011.

[18] http://www.pchemlabs.com/manuals/pdf/eberline-esp2technical-manual.pdf.

[19] ICRP., ICRP Publication 103 recommendations of the

ICRP: annals of the ICRP volume 37/2-4. International Commission on Radiological Protection. Pergamon Pres, 2007.

[20] RESA, Radiation Measurement Systems TAEK (online).

[21] E. Kam, Z. Ü. Yümün, M. Önce \& G. Açıkgöz, "Gamma

Dose Rate Values In The Kulakçayırı Natural Lake and The Vicinity (Arnavutköy, İstanbul). Journal of Engineering Technology and Applies Sciences, 1(1), 29-33, 2016.

[22] Z. Ü. Yümün, E. Kam \& M. Önce, "Gamma Dose Values of Stratigraphic Units Surfaced in Behramkale (Çanakkale) Zeytinli (Edremit-Balıkesir) Section of Kaz Mountains". Journal of the Turkish Chemical Society Section A: Chemistry, 7(1), 207-2014, 2019.

[23] O. Günay, "Determination of Natural Radioactivity and Radiological Effects in some Soil Samples in Beykozİstanbul'. European Journal of Science and Technology. 12, 2018. 